\title{
The Role of the Market Model in Corporate Law Analysis: A Comment on Weiss and White
}

\author{
Merritt B. Fox†
}

In a recent article, Elliott Weiss and Lawrence J. White sought to establish that seven decisions of the Delaware courts concerning corporation law had little value in predicting the future conduct of courts and corporations under the Delaware Corporations Law. Weiss and White relied, in part, on a statistical analysis of changes in the prices of publicly traded shares in Delaware corporations to show that the seven studied decisions had no statistically significant market impact.

In this Comment, Professor Fox takes issue with the explanation Weiss and White give for their data. Although the absence of an observed market impact might demonstrate the insignificance of the judicial decisions, Fox argues, it more likely demonstrates the limited capacity of market studies to reveal changes in the actual value of shares of stock resulting from such decisions.

In Part I, Fox states and defends his assumption that judicial decisions do have predictive value regarding the future conduct of courts and corporate actors. In Part II, he examines the justifications offered for the conclusion that market study techniques provide reliable evidence that the seven decisions Weiss and White studied had no impact on share value. In Part III, he argues that the market model is not well equipped to discern the significance of events like judicial decisions. Finally, in Part IV, Professor Fox examines the significance of the results of the Weiss and White study for the current debate among corporate scholars concerning the contractual model of corporate law.

\section{INTRODUCTION}

One of the notable achievements of modern finance theory has been the use of the market model for studying the reaction of share prices to new information. This technique was originally developed to test market efficiency, the speed with which the market fully reflects new information concerning an event of obvious importance to the value of the shares

$\dagger$ Professor of Law, University of Michigan Law School. B.A. 1968, J.D., 1971, Ph.D. (Economics), 1980, Yale University. The author wishes to express his appreciation to Dean Bryant G. Garth, Professor Ann J. Gellis, Professor J. Wilham Hicks, Professor Frederick Schauer, Professor Joel Seligman, and Professor Michael B.W. Sinclair, each of whon read an earher draft of this Article and offered helpful comments. 
involved. However, once a significant number of finance theorists were persuaded that market prices reflect information concerning such an event very quickly after it becomes publicly available, the market inodel was used for a broader purpose: to measure the effect of particular kinds of events on share value. This second apphication of the market model has been used increasingly by commentators on laws regulating firms and their inanagements. The magnitude of the market reaction thus has been regarded as a measure of the effect of such events on share value.

The recent article by Elliott Weiss and Lawrence J. White in the March 1987 issue of the California Law Review is a provocative example of this trend. ${ }^{1}$ The authors selected seven Delaware judicial decisions concerning legal constraints on corporate manageinent as "events." Each "appeared to make significant, unanticipated changes in Delaware corporate law."2 Because such legal changes would have altered the motivational structure within which the managements of Delawareincorporated firms worked, one would expect the decisions to have had at least some effect on the value of the shares of Delaware firms. ${ }^{3}$ In fact, much of the debate among corporate law scholars about these decisions has concerned whether the effects are positive or negative. ${ }^{4}$ Weiss and White, however, find no statistically significant market reaction to the announcement of any of the seven decisions. ${ }^{5}$

Weiss and White behieve that the "most powerful"6 explanation of their results is that '[i]nvestors do not believe that the Delaware courts' decisions in corporate governance cases - even cases viewed by virtually all commentators as doctrimally and practically significant-cause meaningful changes in the value of the stock of Delaware companies."7 From this explanation they concluded that "the doctrinal changes that the courts announced in those decisions do not foreshadow predictable differences in the outcomes of substantial numbers of future corporate governance cases." 8

1. Weiss \& White, Of Econometrics and Indeterminacy: A Study of Investors' Reactions to "Changes" in Corporate Law, 75 CALIF. L. REv. 551 (1987).

2. Id. at 553.

3. Share value, as it is used in this Article, means the aggregate future stream of income accruing to the holder of a share discounted to present value. The market model is a method of ascertaining the reaction of share price to news of a particular event. Thus the use of the market model to test the effect of an event on share value assumes that the reaction of share price to news of the event is the most accurate available measure of the effect of the event on this discounted income stream. For an elaboration of the relationship between share value and share price, see Fox, Shelf Registration, Integrated Disclosure, and Underwriter Due Diligence: An Economic Analysis, 70 VA. L. REv. 1005, 1010-14 (1984).

4. Weiss \& White, supra note 1 , at 553.

5. Id. at 553,582 .

6. Id. at 554 .

7. Id. at 593.

8. Id. at 601 . 
This Comment argues that the results of the Weiss and White study are better explained as evidence of the inadequacies of the market model when used to measure the effects of events such as the seven decisions on share value. While Weiss and White mention as an alternative explanation the possibility that a market model event study is an inappropriate technique for evaluating the effects of such decisions, they fail to give it serious consideration. It will be seen that this alternative explanation shighted by Weiss and White has more damaging implications than the one they embrace for two mainstays of modern corporate law scholarship: empirical work using the market model and the contractual theory of the corporation.

How one explains the Weiss and White results depends on one's assumptions. If one assumes that the seven decisions have value for predicting future judicial behavior, the results suggest problems inherent in the use of the market model to measure the effects of events such as judicial decisions. However, if one assumes, as do Weiss and White, that there are no significant problems with the market model, the results are evidence that the decisions lack predictive value. Choosing the better explanation involves determining which assumption is more plausible. ${ }^{9}$

9. In their response to this Comment, Weiss and White state that my alternative explanation of their results "represents a fundamental inversion of standard social science methodology." Weiss \& White, A Response to Professor Fox, 76 CALIF. L. REv. 1047, 1048 (1988) (hereinafter Response). They say that their study is a test of the hypothesis that the seven decisions represented changes in Delaware law that "investors would consider significant" and, indirectly, of whether the decisions in fact changed the laws "in ways that were economically significant." Id. They emphasize that in contrast to their effort to empirically test the validity of this proposition, I simply assume it. In doing so, they claim that I am acting in a fashion that suggests "all the empirical branches of the social sciences could cease their efforts." Id. at 1051. While it is not inappropriate for me "to criticize the specifics of [their] empirical tests," they assert, "such criticisun should leave one agnostic and eager to evaluate alternative tests." Id.

This line of argument presupposes that their hypothesis is the ouly one that can be imvestigated by their empirical findings. In fact, these findings can also be used to investigate an alternative hypothesis-that the inarket inodel is an effective way of measuring the effects on share value of events such as the seven decisions. Weiss and White are iguoring a basic axiom of social science. An enpirical study is necessarily a joint test of the theory used to conduct the study (in this case the market model) and of a theory concerning the effects of the phenomenon under examination (in this case, the effects of a certain kind of judicial decision). For empirical findings to be mcaningful, one must inevitably choose which theory is to be assumed valid and which is to be tested.

The arbitrariness of the argument in the Weiss and White response is revealed in their original article. To suggest that they began their study with the intention of testing whether major Delaware corporate law decisions in fact have any effect on share value would be the real fundamental inversion here. It appears that their initial inotivation was to see whether the direction of the effects of the seven decisions on share value corresponded to what was predicted by adherents of the contractual theory of the corporation. Weiss and White found the absence of market reactions "surprising." While "retaining [their] belief that investors, as embodied in 'the market,' generally understand ... . the significance of events that have the potential to affect the value of corporate stock" (thereby assuming the empirical validity of a critical proposition), they "proceeded to reexamine the other premises on which [they] had based [their] study." Weiss \& White, supra note 1 , at 553 (emphasis added). Thus, the central problem addressed by both Weiss and White's original 
Part I of this Comment considers the assumption adopted by this author-that decisions such as those studied by Weiss and White have predictive value-and briefly shows why most readers will find it highly plausible. Parts II and III examme the assumption adopted by Weiss and White-that the market model has no significant problems-and find it more questionable. The market may not have effectively noticed the seven decisions. If it did, its evaluations of their effect may not have been correct. And even if the market did take notice, its evaluations were correct, and the changes in share value were substantial enough to merit the concern of legal scholars, the observed price changes that accompanied the decisions nray well not have been large enough, given the level of background "noise" in stock prices and the inevitable linitations of available statistical nethods, to be considered statistically significant. Part IV explores the coinparative implications for corporate law scholarship of the contpeting explanations of the Weiss and White findings.

\section{The Assumption that Judicial Decisions Have Predictive Value}

Since the plausibility of the assumption that judicial decisions have predictive value is central to my interpretation of the Weiss and White results, a brief analysis is in order. Let us begin by clarifying our terms. Imagine a hypothetical corporate governance case, Smith $v$. Jones, which like the decisions selected by Weiss and White is generally viewed as making a significant, unanticipated change in doctrme. Every judicial decision arises out of a particular factual situation in which soineone comes before a court and seeks rehef. Smith $v$. Jones can be said to have predictive value if a well-informed observer, by virtue of his knowledge of the Smith v. Jones holding, can more accurately predict at least one future court's response to another such factual situation. ${ }^{10}$ It is impor-

article and this comment is how to explain the "surprising" results, not how best to test thc hypothesis they set out in their response. Weiss and White's study is an important contribution to the corporate law literature. However, their suggestion that only their explanation of the results represents sound social science is not equally helpful to the scholarly enterpise.

10. For a predicted change in judicial behavior to affect the valuc of Delaware shares, two additional assumptions are necessary. First, it must be assumed that corporate management cannot avoid the factual situations that would give rise to cases for which Smith $v$. Jones has predictive value simply by fulfilling some formal requirement of no consequence to shareholder welfare. Second, the relief that a court grants in such cases should affect the welfare of the parties to the cases. These additional assumptions are, however, almost certainly correct if Smith v. Jones is like the Weiss and White decisions. To assert that the first assumption is incorrect as to all seven "major" decisions would be tantamount to claiming that corporate law as a whole is a mere formality with no real effect on shareholder welfare. Nothing in Weiss and White's description of court behavior suggests that they make that claim. Id. at 60405. A review of the relief sought in each of these seven decisions makes clear that the decision of the court would affect the welfare of the parties. Since subsequent cases would be likely to involve requests for similar relief, it is evident that the second 
tant to note that nothing in this definition of predictive value requires that the facts of the possible second case correspond to the facts highlighted by the doctrinal statements im Smith v. Jones.

The assuniption that Smith $v$. Jones has predictive value cannot be tested directly. To start, it would not be possible to gather two groups of well-informed observers, one that knows of Smith $v$. Jones and another that does not, to compare their performance in predicting judicial behavior in some set of subsequent cases. Since a well-informed observer, by definition, is familiar with major decisions such as Smith v. Jones, no observers could be found to constitute the second group. Second, it would be difficult to identify with any precision an appropriate set of subsequent cases. The malleability of legal concepts makes it very unclear which subsequent cases are proper candidates for the test, that is, ones which have the potential for being influenced by, or by the same factors as, Smith v. Jones. ${ }^{11}$ Finally, Smith v. Jones may forecast such dire consequences for certain behavior that a case based on such behavior never arises.

Given the impossibility of directly testing the assumption that cases have predictive value, one's conclusions about whether the assumption is plausible depends on how one feels about the implications of the assumption being false. As an initial observation, rejecting the assumption that cases have predictive value is at odds with the behavior of most members of the legal profession. A law professor who disbelieves the assumption would not teach from a casebook. A practicing lawyer who disbehieves it would not consult a treatise or research cases before counseling a chent.

The fact that most persons in a group behave in a certain way does not by itself prove the behavior is rational, but behind this behavior is a legal consciousness with a rich tradition. This consciousness represents a faith that there is value in analyzing problems in accordance with traditional legal classifications. The attack on traditional legal consciousness by the legal realists and more recently by critical legal scholars has been successful to the extent that today few legal scholars, practitioners, or judges believe that they can successfully perform their tasks solely by this form of analysis. However, as will be developed immediately below, their unwillingness to abandon this traditional consciousness entirely

assumption-that judicial relief affects shareholder welfare-is also correct with respect to each of the seven decisions.

11. The concept of malleability is developed below. See infra notes 13-14 and accompanying text. The very fact that legal concepts are malleable might lead one to conclude that Smith $v$. Jones lacks predictive value without even being concerned about testing that proposition. However, merely because one cannot objectively identify at the outset which subsequent cases may be influenced by Smith $v$. Jones does not mean that it will not, in fact, have some predictive value as the term has been defined here. 
indicates how extreme the claim is that judicial decisions have no predictive value.

In describing corporate law as "indeterminate," Weiss and White are borrowing a term from the critical legal studies movennent. ${ }^{12}$ At the core of the complex concept of indeterminacy is the idea that authoritative sources such as doctrinal statements in prior judicial opinions do not compel a judge to come to a particular outcoine in any subsequent case. Doctrinal materials cannot objectively resolve the questions raised by the case because the materials are sufficiently complex that each side can argue, by manipulating the level of specificity and the characterization of the facts, that the outcome it desires is authoritatively required of the judge. ${ }^{13}$ This characterization of judicial behavior suggests that the existence of Smith $v$. Jones cannot compel a judge to come to a particular result in a subsequent case. Nothing im the characterization, however, demies the possibility developed below that Smith $v$. Jones will be helpful in predicting the outcome in a subsequent case, either because Smith $v$. Jones may influence the judge in the subsequent case or because the judges in the two cases are influenced by common factors. ${ }^{14}$

For a variety of reasons, a judge in a subsequent case may adhere to what Smith v. Jones appears to require. The doctrinal statement in Smith v. Jones may shape the expectations of the judge's relevant constituencies and he may be concerned with how they greet his decision in the subsequent case. ${ }^{15}$ The judge may also value judicial predictability. ${ }^{16}$ If law is, in fact, mdeterminate, the judge may be able to generate a respectable legal argument for deciding the case the other way. However, generating such an argument may require a large amount of time and energy. He may not care enough about coming out the other way to allocate these resources to this particular cause. ${ }^{17}$ Also, although his value preferences may initially lead him to desire a result contrary to that which Smith $v$. Jones appears to require, he may be convinced of the wisdom of the Smith v. Jones outcome in the process of formulating his

12. Weiss \& White, supra note 1 , at 602 .

13. See, e.g., Unger, The Critical Legal Studies Movement, 96 Harv. L. Rev. 561, 570-73 (1983); Yablon, The Indeterminacy of the Law: Critical Legal Studies and the Problem of Legal Explanation, 6 CARDozo L. REv. 917, 917-18 (1985).

14. Some critical legal scholars who advance the view that law is indeterminate explicitly recognize that it is often possible to make reliable predictions of judicial decisions and that doctrine can be useful in making such predictions. Singer, The Player and the Cards: Nihilism and Legal Theory, 94 YALE L.J. 1, 19-25 (1984); Yablon, supra note 13, at 918-19, 921.

15. Singer, supra note 14 , at 24 .

16. Id.

17. See Kennedy, Freedom and Constraint in Adjudication: A Critical Phenomenology, $36 \mathrm{~J}$. LEGAL EDUC. 518, 528 (1986). Kennedy ultimately concludes that the question of whether it is difficult or impossible to come up with a convincing counterargument to what existing authoritative materials appear at first blush to require is an empirical question about the real experiences of judges. Id. at 547-48. 
counterargument. ${ }^{18}$

Even if the doctrinal change contained in Smith $v$. Jones does not influence judges in subsequent cases in the ways just described, it may nevertheless reflect an unarticulated change in the court's policy preferences. Such preferences inay well not undergo further change for a period of time. Thus, there are a variety of reasons why most readers will find highly plausible the assuinption that the Weiss and White decisions, which like Smith $v$. Jones are generally viewed as making a significant, unanticipated change in doctrine, have predictive value. ${ }^{19}$

\section{II}

\section{The Accuracy With Which Share Prices Reflect THE EFFECT OF THE SEVEN DECISIONS ON SHARE VALUE}

Having estabhished the plausibility of the assumption that decisions such as those studied by Weiss and White have predictive value, let us now examine the assumption, adopted by Weiss and White, that the market model accurately measures changes in share value that would result from the seven decisions. The first part of this mquiry, and the subject of this section, concerns whether share prices themselves-the raw data fed into the market model-accurately refiect changes in share value. I find the claim that they do rests upon two highly questionable premises. First, this claim requires that any event that changes share value be rapidly noticed by market participants and incorporated into share price. Second, it assumes that the price reaction that occurs accurately reflects the change im share value. Each of these premises is problematic given the nature of the information under study.

\section{A. The Reaction of Share Prices to Information}

Finance theory contains a large body of literature that evaluates the market reaction to particular kinds of information in which the shares of the affected firms experience statistically significant abnormal returns at

18. Id. at 548-51.

19. In their response to this Comment, Weiss and White state that they do not deny that decisions have predictive value in the sense of "providing lawyers with guidance concerning how courts are likely to deal with certain claims." Response, supra note 9, at 1050. The relevance of this statement to the debate between us is unclear. The definition of "predictive value" set out here relates to how courts respond to underlying factual situations, not "claims." See supra note 10 and accompanying text. This is exactly the kind of predictive value that Weiss and White deny when they say in their original article that "the doctrinal changes that the courts announced in [the seven] decisions do not foreshadow predictable differences in the outcomes of substantial numbers of future corporate governance cases." Weiss \& White, supra note 1, at 601 (emphasis added). The foregoing discussion deals with evidence of the predictive value of cases like Smith $v$. Jones for lawyers who are counseling clients trying to decide how to behave, not their predictive value for lawyers who are framing claims in litigation. 
the time the information is officially announced and, starting almost immediately thereafter display normal returns for the duration of the study. Included within this body are many of the studies that Weiss and White cited as examples of the market's ability to incorporate new information concerming judicial opinions or of the market model's value in measuring the effects of certain other events on shareholder wealth. ${ }^{20}$ This pattern of returns suggests that the market quickly notices and incorporates the kinds of information studied into share prices. This pattern of returns also suggests an efficient market in the sense that it would be impossible on average to inake trading profits, in the case of positive information, by purchasing shares after hearmg the announcement (by which point the returns would have returned to normal) and selling them at some later point within the duration of the study.

Before we can conclude, however, that the market also noticed and reacted immediately to the news of the seven Delaware decisions, ${ }^{21}$ we need to determine whether there are any differences between the seven decisions and the kinds of information involved in these earher studies. This question is important because it relates to the origins of the wide behef in the "semi-strong" form of the efficient capital market hypothesis. Briefly stated, this hypothesis holds that once a new piece of information is "publicly available," that is, known by some mimmum number of corporate outsiders, the price reacts immediately "as if" all investors know the information when clearly not all of them do. ${ }^{22}$ Belief in this hypothesis has developed without an exphicit causative theory. ${ }^{23}$ Rather,

20. See Weiss \& White, supra note 1, at 566-67 \& nn.63-65. Not all of the studies cited by Weiss and White showed statistically significant abnormal returns at the time of the announcement of the information. The studies that failed to show such abnormal returns are not evidence that the market rapidly incorporated the information involved. This is because the absence of abnormal returns is as consistent with the proposition that the inarket simply did not notice the event as it is with the proposition that it noticed the event but did not regard that event as important.

21. The proposition under question, stated more precisely, is that the market noticed and reacted to the seven decisions and that the lack of statistically significant abnormal returns demonstrates that it concluded that the decisions were unimportant.

22. For a discussion of this concept, see Beaver, Market Efficiency, 56 AccT. REv. 23, 28 (1981); Fama, 25 J. FIN. 383, 383 (1970); Gilson \& Kraakman, The Mechanisms of Market Efficiency, 70 VA. L. REv. 549, 554-58 (1984).

23. There is no simple intuitive model of individual behavior consistent with portfolio choice theory (which is at the heart of the modern study of finance) that would lead one to believe that share prices would react as described by the efficient capital market hypothesis (ECMH). At first blush, one inight think that market efficiency could be explained by a simple arbitrage mechanism. If an investor possesses a piece of information not possessed by others that suggests, for example, that the current share price of the affected firm is too low, she would begin buying the firm's shares and continue to do so until her actions, perhaps combined with the actions of other similarly informed investors, create sufficient demand that the market price increases to fully reflect the information. See, e.g., Easterbrook \& Fischel, The Proper Role of a Target's Management in Responding to a Tender Offer, 94 HARV. L. REV. 1161, 1165 (1981). This mechanism is inconsistent, however, with portfoho choiee theory which instructs the investor how to construct a portfolio that, given her tastes, has the optimal tradeoff of return for risk. The shares of such a firm 
its proponents have relied primarily on empirical studies. It is not at all clear, however, that results which have been empirically demonstrated for one kind of information are persuasive with regard to another, unstudied kind of information. ${ }^{24}$

The earher studies concern the impact of such information as the announcements of stock sphits and quarterly earnings, merger and tender offer announcements and the news of their subsequent success or failure, the initiation and disposition of government antitrust actions to prevent or undo mergers, the announcenents of proposed antitakeover amendments to corporate charters, and of standstill agreenents and corporate share repurchases. What distinguishes these prior studies from the Weiss and White study is the number of firms potentially affected by a single piece of information. In each of the prior studies, the information was firm-specific: Under the hypothesis being tested, a single piece of information is expected to affect the share prices of one, or at most a handful, of firms (for example, the firm declaring the stock split, the two parties to a proposed inerger, the competitors of the firms in a proposed merger). As a methodological consequence, each previous study considered a long time period and identified a large number of firm-specific, similar-in-kind pieces of information that were announced during that period in order to obtain a sample of adequate size. For each piece of information, the study observed the share price reaction of the potentially affected firm or firms. The conclusions of each study concern the general effect of the kind of information that the firm-specific announcements represented. The conclusions are based on the average share price reaction (adjusted by the market model) to those many announcements.

By contrast, in the Weiss and White study each piece of information-the announcement by a Delaware court of a corporate law decision-potentially affects all firms incorporated in Delaware and is treated as a unique event that is then evaluated in isolation. Weiss and White's conclusions are based on the average reaction of a sample of Delawareincorporated firms to a single announcement.

The nuinber of firms affected by an event of a given economic magnitude is important to the question of whether the inarket is likely to notice information concerning the event. This is because the inore firms

still do not have a certain return. There is a limit to the number of shares any one investor possessing the new information will purchase because the newly purchased shares dediversify her portfolio. In the sort of utility function typically assumed, after some point additional shares decrease the investor's utility by adding risk more than they increase her utility by adding expected return. This point is more fully developed in M. Fox, FinANCE AND INDUSTRIAL Performance in A Dynamic Economy 36-57 (1987).

24. See Fox, supra note 23 , at $35,54-55$. The results of these empirical studies have generated new theoretical work concerning securities pricing. For a discussion of this work, see id. at 55-57 and infra notes 30-49 and accompanying text. 
that are affected, the smaller the effect on the share value of any individual firm. That in turn reduces the likelihood that the market mechamisms that translate newly available information into share prices will be triggered.

To illustrate why the number of affected firms makes an important difference, let us hypothesize two pieces of information soon to be announced referring to events of equal econonic magnitude. The first concerns a government contract granted to corporation $X$, the shares of which have a current market value of $\$ 500$ million. The contract will mcrease the aggregate discounted expected value of $X$ 's future dividends by $\$ 100$ million. The second is a hypothetical Delaware court decision that increases the aggregate discounted expected value of the future dividends of each of 500 large, publicly traded Delaware corporations by an average of $\$ 200,000$ each. A price reaction to news of the contract requires only that some traders pick up on information of obviously large importance to a single firm and purchase just its shares. This is the same pattern of trading as would be necessary to cause price reactions to the varieties of firm-specific information that were the subject of the earlier studies. Thus the fact that the market reacted quickly to the information tested in these studies suggests that mechanisms exist which will ensure that the announcement of the contract will affect similarly the price of shares in corporation $X$.

The pattern of trading necessary to cause a price reaction to the court decision is different, however. It requires that traders pick up on something of much less importance to any given firm and purchase the shares not of one, but of 500 firms. Because of this difference in the necessary pattern of trading, the earlier studies do not create a similarly strong presumption that mechanisms exist to ensure a price reaction when the court decision is announced.

Although this comparison may be too stark, ${ }^{25}$ the market mechanisms that translate newly available information into share prices are clearly less likely to be triggered by judicial decisions that affect hundreds of firms than by firm-specific information. The amount that any single such judicial opinion changes the constraints on management, even if real, is likely to be small. Thus, as with the hypothetical court decision, there is likely to be little change in the value of the shares-in percentage terms - of any one firm. Rather, the importance of the decision comes from the large number of firms affected. ${ }^{26}$ While this aggregate importance might suggest there are still profits to be made by trading on the information, the transaction costs are substantially higher than those of

25. Studies have suggested market efficiency for firm-specific information considerably less dramatic than news of the hypothetical contract.

26. See infra text accompanying note 56 . 
trading on firm-specific information of equal aggregate importance. Specifically, the speculator faces the additional costs of identifying affected firms and of purchasing the shares of several hundred firms rather than of just one. Also, it is worth noting that advisers to inajor institutional and individual investors tend to specialize by industry. Since a corporate law decision will not have a pronounced effect on any single industry, these advisers inay not pay special attention to it and will not stimulate investors to trade on it.

Another factor that makes corporate law decisions less likely to trigger market inechanisms is the lack of consensus about the direction of their effects on share value, as is evidenced by the debate among legal coininentators concerning Wess and White's seven decisions. In many of the earlier studies, the effects of firm-specific information on share value were clear. The lack of concensus about corporate law decisions, by contrast, discourages trading on news of their announceinent because it is expensive for traders to reach their own conclusions as to the decisions' effects. The lack of consensus also discourages trading because the trader cannot be confident that any prediction he does make, even if right, will be reflected in price in the near term. ${ }^{27}$

These two aspects of corporate law decisions-the sinall effect per share and the lack of consensus as to the direction of the effect-reinforce one another. They tend to create an operating culture among professional traders in which such events are not regarded as worthy of notice, even if they in fact affect share value. ${ }^{28}$

Now that we have examined the premise that new information concerning events such as the seven decisions is rapidly noticed by market participants and incorporated into share price, ${ }^{29}$ let us turn to the second

27. The trader may not trade because he thinks his speculation would require a long-term investment. See infra note 47.

28. This discussion is not meant to suggest that the market is never capable of noticing and quickly incorporating information concerning a large number of firms. For example, one of the earlier studies supporting the semi-strong form of the efficient market hypothesis found the market promptly incorporated Federal Reserve Bank announcements of changes in the discount rate. Waud, Public Interpretation of Federal Reserve Discount Rate Changes: Evidence on the "Announcement Effect," 38 EconomerRICA 231 (1970). Unlike Delaware court decisions, however, changes in the discount rate are of obvious and unambiguous importance to the value of all shares and trading on the basis of such information does not require the identifieation of an affected subset of all securities.

Another example is a recently reported Federal Trade Commission staff study. It found that Governor Cuomo's announcement of a proposed bill desigued to restrict hostile takeovers of certain New York corporations resulted im a statistically siguificant decline in the prices of the affected firms. Schumann, State Regulation of Takeovers and Shareholder Wealth: The Effects of New York 1985 Takeover Statute, (Bureau of Economics, Federal Trade Coinmission, March 1987). This study, however, involved a highly publicized piece of legislation with a clear purpose and was announced at the height of a boom in hostile tender offers. The bill covered 96 firms including soine that were actual or rumored targets at the time of the Governor's announcement. Id.

29. In their response, Weiss and White appear to argue that, contrary to the suggestion here, 


\section{premise-that the price reaction that does occur accurately reflects any change in share value.}

the events examined by their study are similar to events that earlier studies showed to have been noticed by the market and quickly incorporated in prices. Response, supra note 9, at 1051-52. Neither the studies cited in their original article nor the additional ones cited in their response support this argument.

In their original article, Weiss and White cite eleven studies to support the proposition that securities prices rapidly incorporate new information and to describe the kinds of events that market Inodel studies have previously been used to examine. Weiss \& White, supra note 1, at nn. 64 and 66. With one exception discussed at the end of this note, the seven Delaware corporate law decisions are strikingly different froin the kinds of events which are examined by the eleven studies. The aggregate effect of each of the seven decisions is spread over the nearly 700 Delaware firms traded on the New York Stock Exchange plus the hundreds of additional Delaware firms traded on the American Stock Exchange and over the counter. In contrast, in nine of the eleven studies, the effect of the main event being examined was concentrated on a single firm. The other two (Stillman and Eckbo) examined the effects on coinpetitive rivals of firms that are parties to inergers. In Stillman, no inerger affecting nore than three rival firms showed a significant price reaction. In Eckbo, the largest median number of affected rivals inportant enough to be included in any of the samples was seven firms. In both studies, all of the firms affected by each event were, by defimition, in the same industry.

In their response, Weiss and White cite an additional twelve studies involving changes in law. Response, supra note 9, at 1052. Four of thein (Moorc, Bensten, Stigler, and Jarrell (1981)) are studies of the long run reaction of stock prices to the effects of legal changes rather than studies of the iminediate reaction of share prices to the announcement of the change (i.e., event studies). They are, therefore, not relevant to the question at hand.

Five of the other eight studies involve legal changes the effects of which are exclusively or predommantly concentrated on a single industry (Jarrell (1984), Ross, Maloney \& McCormick, Hughes, et al., and Schipper, et al.). In Jarrell (1984) and Ross, the number of important firms in the main affected industry are five and six respectivcly. Maloney \& McCormick and Hughes et al. both consider the effect on the textile industry of the inposition of cotton dust standards by the Oceupational and Safety Health Administration. The number of important firms in the industry was betwecn 14 and 18. There was an extraordinarily high level of public awareness of these standards, their having "attracted more media attention . . . than alınost any regulation issued in years." Hughes, Wesley, Magat \& Hicks, The Economic Consequences of the OSHA Cotton Dust Standards: An Analysis of Stock Price Behavior, 29 J.L. \& ECON. 29 (1986). Even then, the two articles taken together do not clearly establish a stock price reaction to the news. Maloney \& McCormick find statistically significant positive returns on textile stocks for the twelve month period ending the month the Department of Labor announced its intent to impose the standards. This result, however, is clouded by the fact that during such a long period of time many other factors may have systenatically affected the textile industry and hence the price of the shares. Even more troubling, Hughes et al., using a different methodology, found instead weakly significant negative returns, which they describe as "modest evidence" that firms in the industry were negatively affected by the regnlations. Id. at 44 . Likewise, Schipper et al. considered the effect on trucking industry shares of a series of Interstate Commerce Commission (ICC) deregulatory rulings. They studied all of the 27 trucking firms listed on the New York Stock Exchange or the American Stock Exchange that survived the period of study and provided needed disclosure. They found a statistieally significant negative reaction to the ICC rulings taken as a group. According to the authors, this group of rulings was considered by some observers to be so important as to have accomplished by agency action all of the changes that were subsequently enacted legislatively by the Motor Vehicle Carrier Act of 1980 (the bill that statutorily "deregulated" the trucking industry). If so, the rulings undoubtedly constituted the most dramatic change in trucking regulation since the industry's formation. In sum, to the extent that these five industry studies empirieally demonstrated a pricc reaction to the events they examined, the events are substantially different from a corporate law decision of a Delaware court. Their effects are concentrated substantially or wholly on a single 


\section{B. The Relationship Between Share Price Reaction and Change in Value}

Even if, despite the questions raised above, information concerning events such as the seven decisions is rapidly noticed by market participants and incorporated into share price, the question remains whether the change in share price (or, more precisely in this case, the lack of change in share price) ${ }^{30}$ which results from the announcement accurately reflects the change in share value. This question is intimately related to a central issue of this Comment: the wisdom of corporate law commentators' increasimg preference for market evaluations of judicial decisions over other modes of analysis.

We should start by understanding the meaning of the standard claim that the market reaction to new information is "unbiased." Mar-

industry, they are more dramatic, and the number of firms affected by even those events with the widest impact is a tiny fraction of those affected by a Delaware corporate law decision.

The events examined by the remaining three studies, although affecting more firms than the events in the five industry studies, also differ substantially from the kind of event examined by Weiss and White. The Schumann study of the effects of the New York antitakeover statute has already been discussed, supra note 28. The Office of Chief Economist (SEC) study of the Ohio antitakeover statute is very similar. The Ohio statute was passed as part of a successful state effort to block the threatened takeover of Goodyear Tire by Sir James Goldsmith that had been front page news for weeks. The study identified 37 Ohio publicly traded firms that would be the firms primarily affected by the legislation. The Largay \& West study examined the reaction of the Standard \& Poor's 500 price index to announcements by the Federal Reserve of changes in the margin requirements. Like changes in the Federal Reserve's discount rate, trading on the basis of this information does not require the identification of an affected subset of all securities. See supra note 28 . Unlike news of a Delaware judicial decision, almost all active investors become aware of a margin change immediately since it constitutes a change in their rules of play. Furthermore, the study's results provided only weak evidence at best of market reaction to the event being examined.

There is within all these 23 studies one brief discussion of a single test of an event roughly similar to the events studied by Weiss and White. In the middle of a study of antitakeover amendments (an event the effects of which are concentrated on a single firm), Linn and McConnell report on a test they conducted of the market reaction to a change in June 1969 to the Delaware corporation code that reduced the percentage of shareholders required to approve a merger from two-thirds to a simple majority. An Empirical Investigation of "Antitakeover" Amendments on Common Stock Prices, 11 J. FIN. Econ. 361, 389-391 (1983). They did this by examining the monthly average residuals of a sample of 120 Delaware firms for a 49 month period surrounding June 1969 and found statistically significant negative reactions in June and July 1969. This lone test result, however, falls far short of providing sound empirical support for the proposition that the market will generally notice and react to a legal change the effects of which are spread over all Delaware firms. Linn and McConnell themselves warn that "some caution should be exercised when interpreting these results" because "it could be argued that the month zero (June 1969) abnormal return is merely a single observation of a single stock index." Id. at 390 . The need for such caution is evidenced by the fact that in 12 of the 49 months surveyed, the average residuals were abnormally positive or negative in an amount statistically significant at the $95 \%$ level and one more was significantly negative at the $90 \%$ level. Also, the cumulative abnormal return for the 24 month period preceding June 1969 was an extraordinary $+8.191 \%$. All of this suggests that factors other than the change in Delaware law were systematically affecting the prices of the sample firms.

30. The question of whether the White and Weiss tests really show a lack of reaction is explored below. See infra text accompanying notes 51-57. 
ket reactions to information are properly termed unbiased if, on average, they correctly measure the actual change in share value. In other words, they may sometimes overestimate the change in share value and they may sometimes underestimate but the errors tend to average to zero. The studies discussed above which show that the market quickly notices and incorporates certain kinds of information suggest a lack of bias because their data do not reveal abnormal returns after the market first mcorporates the information. ${ }^{31}$ But lack of bias and accuracy are different concepts. ${ }^{32}$ Consider, for example, two investors, $X$ and $Y$, who forecast the effects of court decisions on share value. Both forecasts inight be unbiased, but $X$ would be considered more accurate than $Y$ if the average deviation of $X$ 's estimates from the actual effects of the decisions ( $X$ 's forecast errors) was smaller than the average deviation of $Y$ 's estinates. Thus, the claim that the market's reaction is unbiased is not by itself a powerful reason to rely on the market's evaluation of the effects of any one decision.

Advocates of market evaluations make claims, however, that go well beyond the market being unbiased. For example, Weiss and White claim that "investors, as embodied in the market, generally understand-often with extraordinary sophistication-the significance of events." 33 They suggest that contract-oriented commentators "take it as a given that the stock market usually is the best unbiased indicator of the significance of new information." ${ }^{34}$ Claims that market reactions are more than just unbiased have respectable theoretical and einpirical foundations. However, we need to be careful in how far we take such claims. Specifically, in order to appraise the applicability of these clains to the seven court decisions, we need to consider the kinds of information incorporated by market price at the time the decisions were anounced. The effect of each decision on stare value is not apparent on the decision's face. Therefore the information incorporated by the market includes not only the fact that the decision was rendered, but also the analyses by individual market participants of the decision's effect.

Two theoretical approaches can be used to demonstrate that these analyses, although information not as easily spread as news of the decision itself, nevertheless are incorporated into market prices so as to give the market reaction special accuracy. I will label the two approaches the

31. See supra text accompanying note 20 . For example, if a study of market reactions to announcements of dividend increases shows the almost immediate disappearance of abnormal returns after the announcement's initial incorporation, this would suggest that the markct does not display a pattern of correcting for an initial reaction that consistently overvalues or consistently undervalues the information.

32. See Fox, supra note 3, at 1010-14.

33. Weiss \& White, supra note 1 , at 553.

34. Id. at 558 (emphasis added). 
"market signaling" paradigm and the "consensus forecastimg" paradigm. Neither approach, as explained below, is fully convincing. Let us examine first the market signaling paradigm.

\section{The Market Signaling Paradigm}

The strongest claim made for the accuracy of market prices is that the price of each security is a "sufficient statistic" for all information held by any one or more market participants. In other words, inarket price fully reflects all available information and hence constitutes the most accurate possible prediction of a security's future returns. There exists theoretical work that shows, given rather stylized assumptions, that market prices have this property. Information is regarded as "bits." Each bit has unambiguous implications in the sense that its receipt would similarly alter every investor's view of the probability distribution of a share's future returns. ${ }^{35}$ The theory is built on the idea that eacl investor, knowing that the current price of a security reflects the probability assessments of otler investors possessing information not possessed by him, will take that fact into account in determiming his level of demand for the security. ${ }^{36}$ As the market works toward equilibrium, investors indirectly reveal to each other their respective collections of information bits. Equilibrium will not be reached until the market price reflects all such information through their bids. When combined with the empirical studies that slow that the market reaches a new equilibrium very rapidly in reaction to new information, this theoretical work suggests that market prices liave remarkable qualities.

It is possible to fit the market reaction to an event such as a court decision into the market signaling paradigm by cliaracterizing all the information possessed by each investor-including what he has acquired througl education, experience, and day to day research-as information bits. The investor analyzes the impact of the decision in light of the particular collection of bits he possesses. To the extent that investors' predictions differ, the differences are due entirely to disparities in their information collections. The market price reflects all the bits in all the collections and is therefore the best possible prediction of future returns.

However, regardless of the strengths of the inarket signaling paradigm where the information really is bits of hard data with unambiguous implications, stretching it in the fashion described above is unconvincing.

35. An example of a truly unambiguous bit of information would be news that a firm was to receive a completely unexpected tax refund in an amount equal to five dollars per share.

36. See, e.g., Grossman, On the Efficiency of Competitive Stock Markets Where Trades Have Diverse Information, 31 J. FIN, 573 (1976); Grossman, Further Results on the Informational Efficiency of Competitive Stock Markets, $18 \mathrm{~J}$. ECON. THEORY 81 (1978). A nontechnical summary of these works is found in S. SHEFFRIN, Rational ExPECTATIONS 118-21 (1983). 
An investor's analysis of an event such as a court decision may be based in part on his collection of information, but it has personal qualities as well. Any particular bit will affect one person's evaluation of share value differently than another's. Also, an investor is likely to regard his analysis as something that involves part of himself, not simply the result of his particular collection of bits of information. His sense of self-esteem is hikely to lead him to view it as relatively accurate. The fact that other investors have different evaluations is not, im his view, explained merely by their possessing different bits of information than him. Because of these personal factors, the imvestor is not going to find market prices fully instructive as to the bits of information held by other persons. Where a deviation exists between the opmion of such an investor and the share's market price, he will act, at least im part, on his evaluation.

This view of individual investor behavior as determined by personal evaluations is supported by the fact that many investors incur the costs of acquiring the human capital necessary to becoine market professionals and engage in day to day research. If each such investor thought that market prices were sufficient statistics, he would have no incentive to do so. $^{37}$

\section{The Consensus Forecast Paradigm}

The view of investor behavior as determined by personal evaluations suggests a more plausible model of the market reaction to events such as the seven Delaware court decisions: share price represents an average of the differing opinions of active investors as to the effects of an event on share value. ${ }^{38}$

Although prices generated in a world resembling this more plausible

37. Grossman and Stiglitz raise the paradox that investors would have no incentive to incur the costs of collecting and processing information if prices were really sufficient statistics and try to resolve it in a somewhat different way. They construct a model of securities pricing in which, in addition to uncertainty concerning future returns, there is also an additional source of uncertainty that creates "noise." The noise makes it impossible for an uninformed trader to fully determine the information possessed by informed traders and thereby makes it worthwhile to some investors to collect and process information and to act on it in the purchase and sale of securities. Grossman \& Stiglitz, On the Impossibility of Informationally Efficient Markets, 70 AM. EcoN. REv. 393 (1980). In their model, they choose the supply of risky assets as the additional source of uncertainty, probably because it is relatively easy to model. Another, perhaps more plausible source of noise may be the tendency, suggested here, for investors to take a somewhat egocentric view of the quality of their evaluations.

38. This model need not deny the existence of the mechanism behind the market signalling paradigm. An investor's actions may well be tempered by an awareness that the current share price reveals the evaluations of other active investors and that these evaluations partially reflect information not possessed by him that would influence his evaluation in the same way it infuenced theirs. The point of this model is that the remaining differences among investors are averaged in the pricing process. 
model would not be sufficient statistics, ${ }^{39}$ other theoretical work forms the basis for the shightly weaker claim that over the long run, market prices display smaller forecast errors than the predictions of any individual trader. ${ }^{40}$ The basic idea behind this work is analogous to that of other studies mvolving forecasts by experts about the next period change in an economic variable, such as the gross national product (GNP). These studies show that over the long run a "consensus forecast" for each period that equals the average of the experts' forecasts displays a lower forecast error than does the forecast of any individual forecaster. ${ }^{41}$ A market price that averages the opinions of many traders might display the same properties. Although each trader's forecast is influenced by his particular mode of analysis, the market's averaging process cancels out these forces without sacrificing any of the information possessed by any of the traders in the market.

Forecast averages, however, only have smaller errors than their components under certain conditions. This raises two questions: First, are these conditions met in the case of investor analyses of the effects on share value of events like the seven decisions? and second, even if these conditions are met and market price does have a lower forecast error than that of any individual investor, what role should these market forecasts play in the debate among the legal scholars about the decisions' impact on share value? Let us address these questions in turn.

It can be demonstrated easily that if each individual forecast: (1) is unbiased (in the sense of not systematically under or overestiniating the number being predicted); (2) has the same expected forecast error as every other forecast measured by the variance of the probability distribution which generated the forecast; and (3) has a forecast error that is uncorrelated with the errors of every other forecast, then the expected

39. Where investors act in part on their own information, to some extent at least, the pricing process resembles the situation where investors "naively" view prices merely as constraints and not as carriers of information. In models of this pricing process, the receipt by one investor of information already possessed by one or more other investors increases the expected accuracy of the resulting share price and so price cannot be a sufficient statistic. See, eg., the models in Grossman \& Stiglitz, supra note 37; M. Fox, The Role of Finance in Industrial Organization 403-27 (1980) (unpublished Ph.D. dissertation available at the Yale University Library). The basic idea is that the market price is a function of some kind of weighted average of the individual investors' evaluations of the security's future returns discounted to present value. Each investor's evaluation is unbiased but its accuracy depends on the level of the investor's information. An improvement in the accuracy of any one investor's evaluation thus increases the accuracy of market price as an estimate of actual value.

40. See, eg., Verrecchia, On the Theory of Information Efficiency, 1 J. Accr. \& EcoN. 77 (1979) [hereinafter Theory of Information Efficiency]; Verrecchia, Consensus Beliefs, Information Acquisition, and Market Information Efficiency, 70 AM. ECON. REV. 874 (1980) [hereinafter Consensus Beliefs].

41. See S. SHEFFRIN, supra note 36, at 115-16; Gilson \& Kraakman, supra note 22, at 581 \& n.103. 
forecast error of the average of the forecasts will be lower than that of any individual forecast. ${ }^{42}$ In the case of real investors who base their participation in the securities markets on their predictions of the effects that events such as the seven court decisions will have on share value, only the first condition is satisfied. ${ }^{43}$ While the average forecast will continue to be superior to any individual forecast if the second and third conditions are relaxed somewhat, ${ }^{44}$ in fact the failure of the third condition is likely to be radical. Deviations between individual forecasts and the true effect of a decision on share value are likely to be highly correlated because most forecasts will be affected substantially by a common body of thought and information. ${ }^{45}$ This creates the opportunity for a dissenter to display a lower forecast error than the market as a whole.

Slow, weak feedback about the ultimate impact of events on share value increases the possibility that a particular trader using an unorthodox approach will make more accurate forecasts. This is exactly the type of feedback one would expect with regard to Weiss and White's seven Delaware decisions. The seven decisions change the legal constraints

42. S. SHEFFRIN, supra note 36 , at $115-16$.

43. There is no reason to think that an individual trader will be either systematically optimistic or pessimistic when evaluating the effect on share value of a variety of court decisions dealing with differing issues and displaying differing outcomes.

44. The inodels developed by Verrecchia assuine differences in the expected forecast error of different investors but find that if the forecast errors are independent and investors are sufficient in number, the market price has the lowest forecast error. See Theory of Information Efficiency, supra note 40; Consensus Beliefs, supra note 40. Even where there is dependence, the market will still have a lower forecast error than the best informed investors if the pricing process correctly weighs the evaluations of the individual investors.

Figlewski constructs a model that explores the potential for wealth transfers from investors with poorer forecasting ability to those with better forecasting ability to increase the relative efficiency of Inarket prices over time. Figlewski, Market "Efficiency" in a Market With Heterogeneous Information, 86 J. PoL. EcoN. 581, 585-92 (1978). The corrective force of such wcalth transfers, however, inay act very slowly.

The author develops elsewhere a model that shows that an investor's awareness of his level of ignorance does not itself result in a market pricing process that weighs individual evaluations optimally. In this inodel, investors have infinite borrowing capacity and the salne utility function with a constant absolute degree of risk aversion so that the securities purchases of each depend only upon his (accurate) assessinent of his forecast error and not on his wealth. The evaluations of an investor are the products of particular bits of infornation in his possession out of the universe of all relevant bits. The more bits unknown to all investors (colninon ignorance) and the more known to all investors (common knowledge), the more the market deviates froin optimal weighting. M. Fox, supra note 23 , at $418-27$.

45. Information-gathering by traders, including importantly the opinions of various experts, and the evaluation of this information to make trading decisions is part of a larger process by which the economy ultimately decides which new real investinent projects should bc implemented and who should control those projects already extant. In a study that extensively considers this larger process, the author examines the rules that individual participants and groups use to select the pieces of information to which they respond from all that is available. The rules relate both to the authority of the source and to its content. The author finds that all types of participants share considerable biases, but that this is less true of traders in securities inarkets than of members of corporate hierarchies. M. Fox, supra note 23, at 92-105, 168-206. 
within which management makes certain decisions. This change can affect share value by altering the underlying profitability of Delaware firms or the relative share of profits received by shareholders. However, these effects may take years to develop and, when they do, will be difficult to discern given the many factors affecting the fortunes of firms and shareholders. ${ }^{46}$

One might argue that the question of whether some traders can make forecasts that are consistently superior to those contained in market prices can be answered empirically because any trader possessing this ability should consistently earn trading profits. ${ }^{47}$ Although a number of frequently cited studies suggest that even highly sophisticated investors cannot systematically outperform the market, ${ }^{48}$ their conclusions are controversial. There exists other scholarly work containing sound critiques of the methodologies of the frequently cited studies or reaching opposite conclusions. ${ }^{49}$ Thus the question of whether consistently superior forecasters exist remains unsettled.

Now let us turn to the second issue, nainely, whether the market reaction to events such as the seven decisions should have a role in economic debates among legal and economic scholars about corporate law if, for the sake of argument, we assume that market prices have the low-

46. These feedback problems are in fact exactly the reasons that market model studies are such an attractive way to estimate the effect of certain events on firm value. The importance of these problems is suggested by the strikingly better potential for feedback in situations where it is claimed that market prices constitute very good forecasts. For example, the announcement of Federal Reserve Board policy changes, something of obvious interest to investors, has often resulted in no discernable price reaction and it had been suggested that this occurs because the market predicts the decision precisely. Gilson \& Kraakman, supra note 22, at 588 . Gilson and Kraakman also note that the phenomenon may be due to insider trading). See id. at 588, n.122. The common body of thought and knowledge that infiuences forecasts of these decisions is subject to immediate, easily discernable feedback. A dissenting theory that yields lower forecast errors will quickly become generally accepted.

47. In fact, proof that no existing trader is capable of making systematic trading profits does not necessarily prove that no existing trader is capable of forecasting the effect of court decisions on share value more accurately than the market. Since the typical trader does not hold a share long enough to receive most or all of what ultimately gives it value-that is, the right to receive, for the remainder of the issuer's life, dividends and other shareholder distributions-his profit is largely determined by the price at which he sells. If a trader is capable of a superior evaluation of the effect of an event on future dividends and distributions but the market evaluation of the event (as implied in market price) is consistent over time, then his sale price will not enable him to profit from his superior evaluation. The findings of the literature supporting the ECMH are not inconsistent with this view: The market can be said to display "speculative" or "information-arbitrage" efficiency but not "allocative" or "fundamental-valuation" efficiency. For overviews of these concepts see M. Fox, supra note 23, at 57-59; Gordon \& Kornhauser, Efficient Markets, Costly Information, and Securities Research, 60 N.Y.U. L. REv. 761, 767-70, 825-33 (1985); Wang, Some Arguments that the Stock Market is Not Efficient, 19 U.C. DAvis L. REv. 341, 344-49, 359-62 (1986).

48. See, e.g., Jensen, The Performance of Mutual Funds in the Period 1945-1964, 23 J. FIN. 389 (1968).

49. For discussions of these critiques and counter studies, see M. Fox, supra note 23, at 47-54; Gordon \& Kornhauser, supra note 47 , at 782-86, 838-41; Wang, supra note 47 , at 363-65. 
est forecast errors. The first thing to note is that despite this assumption, the market reaction to any given decision is not necessarily more accurate than the forecasts of some individuals. Because these individuals will not have been able to systematically demonstrate superior forecasting skills, we can not know when the decision is announced who these individuals are and hence which forecasts are superior to that of the market. Therefore, the question of the effect of a given decision on share value is not definitively resolved by the market reaction to its announcement; all that can be inferred from the assumption that the market has the lowest forecast error is that investors cannot consistently make trading profits by trying to outperform the market.

The market reaction to legal developments is part of a larger dynamic process that includes the work of legal and economic scholars. Generally, traders are not themselves experts in corporate law or in the effects of changes in managerial constraints on firm performance. Lawyers and economists are the experts on these questions. The special strength of traders is intelligent evaluation of the disparate opinions of the lawyers and economists. Price reactions to a decision at the time of its amiouncement reflect how persons who "put their money where their mouths are" view the debate among these experts.

The market reaction, while obviously enlightening, should not, as some market model adherents seen to suggest, bring the debate concerning a legal development to an end. Continuation of the debate is likely to further understanding of the complex issues involved even if, because of the assumption here that the market has the lowest forecast error, the debaters will not be able to make consistent trading profits. This point can be illustrated by another analogy to forecasts of key economic variables. The discovery that the average of expert forecasts of GNP growth displays a lower forecast error than the forecasts of any individual does not, and in the interests of society should not, cause economists to cease study and debate about the theories and models behind these forecasts.

There is still another reason why the results of the Weiss and White study should not foreclose debate about the merits of the seven decisions they selected. Weiss and White argue that because the market reaction to each of the seven decisions was not statistically significant, the decisions had hittle effect on share value; therefore, they conclude that these "major" judicial decisions have essentially no value for predicting future judicial behavior. However, even if market prices do have lower forecast errors than any individual, it would be a mistake to conclude that reactions near zero necessarily show that the decisions have no effect on share value. Several of the decisions studied by Weiss and White are controversial, with some commentators behieving in each case that the 
decision adds to share value and others believing it reduces share value. ${ }^{50}$ Each trader is likely to be influenced to a greater or lesser extent by the arguments of each side and there may be considerable variation among traders in their evaluations of the debate. The weighing of the commentators' opposing opinions by each trader and the averaging of those judgments in the pricing process will result in a market reaction to each decision that is closer to zero than are the evaluations of the commentators on either side of the debate. It may well be close enough to zero to be considered not statistically significant. For each decision, one side or the other of the debate might in fact be correct, but the near zero market reaction might display a lower forecast error over the seven decisions than the forecasts of any of the commentators. This possibility is bound to describe, at least to some extent, the actual process revealed by the Weiss and White study. This follows because in statistical theory optimal forecasts should be less volatile than actual outcomes. Tlius, even if the market reaction is the best way of forecasting the effect of each decision on share value, it is not necessarily a good way of measuring the extent to which the effect deviates from zero one way or the other, that is, its absolute value.

\section{III}

\section{The Sensitivity of MARKet Model Studies to Changes in Share Price}

The preceding sections reveal several reasons to believe that the results found by Weiss and White are best explained by limitations of market studies rather than-as they conclude-the insignificance of the seven Delaware decisions for firm value. Let us now turn to yet another reason to discount the Weiss and White conclusion, limits on the ability of their market study to detect share price reactions to the seven decisions.

Let us assume for argument that share prices do accurately reflect changes in share value resulting from the seven decisions. Weiss and White find that the observed price changes at the announcement of the decisions do not constitute a statistically significant reaction. This finding does not necessarily imply that the decisions did not have effects large enough to be importance to legal commentators. ${ }^{51}$ The failure to observe a statistically significant reaction may instead result from the inevitable limitations of the statistical methods employed. The real reaction may

50. See, Weiss \& White, supra note 1, at 552-53.

51. Weiss and White acknowledge that this explanation of their results "may have some validity" but for reasons that they do not explain, consider the lack of predictive value explanation to be more powerful. See Weiss \& White, supra note 1, at 589-90. 
have been large enough to be important but not large enough, due to the existence of "background noise," to register as statistically significant.

A hypothetical example demonstrates that this explanation is plausible. Consider the announcement of a court decision that, according to the best estimate based on all available information, constitutes a clear change in judicial policy that will increase the expected value of future shareholder returns of the average public Delaware corporation by $0.1 \%$. Share prices of Delaware corporations, im accordance with our assumption, will rise commensurately. Other chance factors, however, almost certainly will simultaneously affect the prices of shares in the sample so that the effect of the decision on share prices calmot be ascertained with certainty. Due to these other factors, the observed change in prices (as adjusted by the inarket inodel) inay differ substantially from an increase of $0.1 \% .^{52}$

For the price change that accompamies announcement of the court decision to be considered statistically significant, it must be sufficiently different from zero that one can, with reasonable confidence, reject the "null hypothesis" that the true effect of the decision is zero and that the observed change results solely from other chance factors. The "standard error" is a statistically derived estimate of the tendency of these other factors to cause the observed price changes to deviate from the actual effect of the court decision on prices. Assume for our example a standard error of 0.65 , which is representative of the standard errors in the Weiss and White tests. ${ }^{53}$. The observed adjusted price change would have to be at least $1.3 \%$ before we could reject the null hypothesis with $95 \%$ confidence. $^{54}$ There is less than one chance in twenty that an increase of $0.1 \%$ in the actual value of a sample portfoho will be accompanied by an observed change in prices sufficiently large, that is, $1.3 \%$, to be considered statistically significant. ${ }^{55}$

52. The expected value of the effect on share price of these other factors is zero, but that only means that they are as likely to add to, as to subtract from, the effect of the judicial decision on share price.

53. Table 1 of the Weiss and White article reports the cumulative abnormal returns (CAR's) of the portfohios of Delaware firms at four points after the announcement of the seven decisions. Weiss \& White, supra note 1, at 583. For each of the 28 tests, the standard error is obtained by dividing the reported CAR's figure by the reported $t$-statistic. For the 28 tests, the mean of the standard errors was 0.78 and the median was 0.57 .

54. Weiss and White test the null hypothesis that the true change in prices as a result of the judicial decision is zero by using the $t$-statistic to establish a confidence interval around the observed change that has a 95\% chance of containing the true value of the change. Given the number of observations in their tests, the distribution of the $t$-statistic approximates a normal distribution. The $t$-value for a two-tailed $95 \%$ significance test is approximately 2.0 . With a standard error of 0.65 , this means that the confidence interval will be the observed change in price $+1-(2.0 \times .65)$. Thus, the observed change must be greater than $1.3 \%$ for the confidence interval to exclude zero.

55. This calculation involves the distribution of possible observed values of the price change if the true value of the change iu prices which results from the decision is an increasc of $0.1 \%$. Since 
While a decision that increases the share value of Delaware firms by $0.1 \%$, has effects too small in general to be acconipanied by statistically siguificant price changes, such a decision is certainly iniportant in absolute economic terms. The aggregate value of the equity of publicly traded Delaware firms is estimated to be niore than $\$ 1$ trillion. ${ }^{56}$ There-

the observed change in prices will be considered statistically significant at the $95 \%$ level only if it is an increase or decrease of greater than $1.3 \%$, the question becomes: what are the chances that the observed change will be of that magnitude. Again, because of the number of observations, the distribution of possible observed changes will approximate a normal distribution with a mean of .1\% and a standard deviation equal to the standard error of 0.65 . The required positive change, $+1.3 \%$, is 1.85 standard deviations above $0.1 \%$ and so, based on standard statistical tables for the normal distribution, there is a $3.2 \%$ chance that the observed change in prices will be an increase of greater than $1.3 \%$. The required negative change, $-1.3 \%$, is 2.15 standard deviations below $0.1 \%$ and so there is a $1.6 \%$ chance that the observed change in prices will be a decease of greater than $1.3 \%$. Thus the chance that the observed change will be considered statistically significant is $4.8 \%$ (i.e. $3.2 \%$ plus $1.6 \%$ ).

Weiss and White complain in their response that this calculation ignores that they ran "seven separate tests of seven separate events" and that they did not find "even one" event that yielded a statistically significant result. Response, supra note 9, at 1055. On the basis of these assertions, they ask the question how large the average effect of each court decision would have to be for them to expect to find at least one of the events to yield a statistically significant result. Their answer is $0.6 \%$.

There is, of course, nothing wrong with my calculation. I simply ask and answer a different question. There is a problem, however, with Weiss and White's calculation and that problem is exactly why I asked my question and not theirs. Contrary to their assertion, Weiss and White did find a statistically signifieant price reaction to one decision, Unocal. Weiss \& White, supra note 1 , at 582. They try to dismiss this result because the Unocal CAR's are positive and they expected them to be negative. Response, supra note 9 , at $1055 \mathrm{n}$. 41 . This defense will not do because the issue here is not the direction of the effect but rather the existence of an effect one way or the other. It is certainly possible that the Unocal decision had a positive effect: The Delaware Supreme Court undoubtedly thought its decision was beneficial to the shareholders of Delaware firms generally. Whether the abnormal returns are in the direction that Weiss and White expected is irrelevant. As an alternative defense, they point out that they found "no significant difference between changes in stock prices of Delaware and non-Delaware companies following Unocal." Id. But this defense just shifts our attention to the fact that there were two other decisions, Singer and Lynch II, which were followed by significant differences betwecn the price changes of Delaware and non-Delaware companies. Id. Despite the existence of some significant CARS, I am willing to accept Weiss and White's characterization of their overall resuits as not showing a statistically significant reaction to the seven decisions. They should not, however, bootstrap this characterization into a blanket assertion that they did not find a significant reaction to even one event and use that assertion as the basis of their calculation.

Using their calculation, Weiss and White go on to conclude that their results permit them to reject the claim that the average effects of the seven decisions were greater than $0.6 \%$ but that they "could not rule out smaller effects." Id. at 1055. Thus, even if their calculation were correct, they are admitting that, given the aggregate value of all Delaware shares, the average effect of the seven decisions may have been as great as $\$ 6$ bilion each. While they suggest that such an aniount may be de minimis, that suggestion is not really tenable. See infra note 57.

56. The value of all stock available for trading on the New York Stock Exchange (NYSE) as of May 31, 1987 was $\$ 2.6$ trillion. Approximately $44 \%$ of the firms registered on the NYSE are incorporated in Delaware. This percentage was calculated from the Directory of Listed SecuritiesStocks, 1 N.Y.S.E. Guide (CCH) 725 (1987). If we assume that the average size of Delaware firms is no smaller than the average size of all NYSE firms, the aggregate value of all Delaware NYSE firms is at least $\$ 1.15$ trillion (i.e. $44 \%$ of $\$ 2.60$ trillion). Such an assumption is reasonable because Baysinger and Butler have found that Delaware is particularly hospitable for corporations with less 
fore, the aggregate effect of the decision would be more than $\$ 1$ billion. ${ }^{57}$

The example of $0.1 \%$ is not farfetched. One would intuitively expect this to be the order of magnitude of the effect on share value of even a major corporate law decision signaling a clear change in judicial policy. In terms of sliaping managerial behavior in ways that affect the corporation's underlying income stream, such a decision changes only one component of the legal constramts on management, which in turn constitute only a portion of the motivational structure within which management works. In terms of affecting the outcomes of actual litigation and of bargains struck in their shadows, such a decision may have dramatic effects over time on the division of corporate wealth between the shareliolders and managers of a certain number of firms, but it is impossible to identify in advance which firms will be so effected.

Thus, the sensitivity of the statistical tests employed by Weiss and White is mevitably limited by the effects of background noise on observed price changes. These limitations are sufficiently grave that, as our hypothetical example shows, the armouncement of decisions with effects on share value of obvious importance in the aggregate are very unlikely to be accompanied by statistically significant price changes. It therefore seems mappropriate to conclude, as do Weiss and White, that their failure to observe such price changes shows that the decisions constituted no significant changes $\mathrm{m}$ policy.

\section{IV}

\section{The Implications of the Weiss and White Results FOR CORPORATE LAW SCHOLARSHIP}

The preceding discussion demonstrates that it is more plausible to assume that major judicial decisions provide at least some guidance as to how future courts will behave than it is to assume that market studies can measure accurately the effects of events such as the seven Delaware decisions on share value. Thus, contrary to the conclusions of Weiss and White, the failure to observe statistically significant price changes accom-

concentrated share ownership and broad ownership should correlate positively with size. See Baysinger \& Butler, The Role of Corporate Law in the Theory of the Firm, 28 J.L. \& ECON. 179, 190 (1985); see also R. POSNER \& K. SCOTT, ECONOMICS OF CORPORATION LAW AND SECURITIES REGULATION 111 (1980).

57. Weiss and White state in their response that "reasonable people can differ as to whether a $0.1 \%$ change is 'important in absolute economic terms' in light of the other cvents that ... create the considerable amount of variability that we ineasured in our samples." Response, supra notc 9, at 1054-55. In making this statement, Weiss and White incorrectly equate statistical significance with economic significance. A judicial decision that reduces the discounted aggregate future cash flow to sharcholders of Delaware firms by $\$ 1$ billion is a discrete act which, unless changed, imposes a permanent loss on society regardless of the effects of these other factors. No reasonable person would regard such a governmental act as unimportant simply because other things affect the value of Delaware shares as well. 
panying the announceinents of the seven decisions is better understood as evidence of the limitations of inarket studies than as evidence that major judicial opinions lack predictive value.

The choice of explanation has important implications for corporate law scholarship. Weiss and White suggest that their explanation is diffcult to reconcile with what is today probably the dominant analytical approach to corporate law, variously labeled as the "Chicago school," "nexus of contracts" or "agency cost" approach. They maintain that adherents of this approach ("contractual theorists") "construe courts" doctrinal statements as elaborations of the shareholder-manager 'contract' designed to allow one to predict with considerable confidence how a court will resolve all future controversies involving transactions or issues similar to those involved in the cases in which those doctrinal statements were made." 58

As developed below, however, it is not at the heart of the contractual approach to view doctrinal statements in judicial opinions as clearly articulated, broad rules the very words of which become imphed terins in the contract. If my explanation of the Weiss and White results is correct, those results pose a far greater challenge to the contractual approach than does the Weiss and White explanation. Moreover, those results suggest the need for caution in accepting the conclusions of other empirical work in corporate law which rehes on the market model. ${ }^{59}$

\section{A. The Contractual Approach: Is Judicial Adherence to Doctrinal Statements a Cornerstone?}

As a normative theory, the contractual approach views the purpose of corporate law as the maximization of social wealth. Its basic elements are as follows: (1) the articles of incorporation form a "contract" between the shareholders and managenent that incorporates by reference the provisions of the corporation laws of the state of incorporation, both statutory and judge made, to the extent that these provisions do not contradict the terms of the articles; (2) this contract should be enforced, with linited exceptions, im accordance with its terms; (3) where the contract, including its incorporated terms, does not cover the litigated issue, the court should imply the term it beheves the parties would have agreed to, ex ante, had they addressed the question.

In application, the first two elements allow managers of publicly

58. Weiss \& White, supra note 1 , at 594.

59. The Weiss and White study makes a particularly good check of the market model. If the market model does measure effects on share value accurately, then the proposition that its results support-that judicial decisions have no predictive value-involves a question about which there is other readily available evidence. This is not true of many other matters tested by the market model, for example, the effect on share value of reincorporation in Delaware. 
held corporations a great deal of discretion because the articles typically contain only broad inandates. This discretion is justified as wealth maximizing because it is the result of a voluntarily created relationship by shareholders and managers that involves no third parties. Each party presunably knows its own best interests better thian a court. This discretion is also justified because of the existence of a number of other forces that tend to align the interests of inanagers with those of shareholders: the market for corporate control; the managerial labor market; and the evolutionary process that causes capably inanaged firms to grow and poorly managed firms to shrink because of differences in profits and access to external capital.

The apphication of the third eleinent of the contractual approach requires a court to decide issues not resolved by the contract in accordance with rules that will cause shareholders and managers to behave in ways that inaximize wealth. ${ }^{60}$ Because of the faith that contractual theorists have in the other forces that align the interests of shareholders with inanagement, they tend to urge the courts to adopt rules which also grant managers a great deal of discretion.

Nothing in this account of the contractual approach requires, as Weiss and White claim, that doctrimal statements in judicial opinions be regarded as broad rules the very words of which becoine implied terms of the contract. Admittedly, contractualists would see advantages to society if courts, when they perform their role in colmection with the third element, clearly articulate broad rules and thereafter adhere to them. ${ }^{61}$ Such a practice inakes future judicial behavior over a wider range of circuinstances easier to predict. As a result, it both facilitates the workings of the contractual approach's first two eleinents and reduces the volume of litigation. Contractual theorists would see disadvantages in such judicial practices as well, however. Because broad rules are not tailored to fit each of the wide variety of circuinstances to which they apply, they inevitably encourage soine inefficient behavior. This problein can be avoided by a case by case, efficiency-oriented kind of judicial decisionmaking with the saine kind of richness-though perhaps with a different aim-as the judicial process Weiss and White describe. Such a practice permits

60. It would be in the interest of both parties to agree on terms that maximize their joint wealth because doing so gives them the most returns to divide. In an injunctive action, the court has the opportunity to order the parties before it to behave in a wealth maximizing fashion. In an action for damages, the behavior of these parties is past and so, as to these parties, the court's decision involves only the division of wealth between them. The precedential impact of the case, however, will influence the future behavior of shareholders and managers in similar situations, and so even damage actions must, in the contractual approach, be decided according to rules which promote wealth-maximizing conduct.

61. A broad rule of this kind can be rationalized as the rule to which the parties would agree ex ante if they were to decide on a rule to cover the range of circumstances covered by the breadth of the rule. 
courts to tailor different rules to fit the needs of each different set of circumstances. While a judicial practice of narrow tailoring may make future judicial behavior more difficult to predict, it does not make it inherently unpredictable. The ability to make reasonably reliable predictions of judicial behavior when judges follow a practice of narrow tailoring is what makes skilled practitioners worth the fees they charge. Contractual theory is thus perfectly compatible with Weiss and White's explanation of their results: Courts, whatever their written opinions say, engage in narrow tailoring and produce outcomes (who wims and who loses under the particular circumstances) that are, for good or for bad, unsurprising. Therefore, according to this view, the seven decisions did not cause the market to change its view of the share value of Delaware corporations because the market predicted those decisions accurately. ${ }^{62}$

\section{B. Problems with the Market Model and the Contractual Approach}

This Comment, however, argues that the Weiss and White results are best explained by the himitations of the market model, and hence they pose a far more serious challenge to the contractual approach. To start, consider the emphasis that the contractual approach places on the language of the articles of mcorporation. The rationale is that the articles are the product of a voluntary relationship of shareholders and management. No one would seriously suggest, however, that most stock purchasers are actually aware of the terms of the articles of imcorporation, let alone capable of accurately evaluating their imphications. Instead, the contractualists assert that the share price, by reflectimg this information and its imphications, does these things for the purchasers and thereby creates incentives for management to draft wealth maximizing terms ${ }^{63}$ and ensures that the contract provides a fair deal to shareholders.

Evaluations of the seven decisions and of the complex provisions of corporate articles mvolve information that is similar in kind. Like judi-

62. One contract theorist, Daniel Fischel, would have more difficulty explaining the results in this fashion since he has characterized some of the seven decisions as retreats from Delaware's traditional tendency to give management broad discretion. See Fischel, The "Race to the Bottom" Revisited: Reflections on Recent Developments in Delaware's Corporation Law, 76 Nw. U.L. REV. 913 (1982). For a discussion of Fischel's comments, see Weiss \& White, supra note 1, at 557.

63. It can be shown that management's utility gain from any deviation from behavior that maximizes share value will not be as great as the utility loss that would result if management's wealth position were diminished by the full amount that the deviation decreases the value of the firm. An accurate price would discount fully for management's ability to deviate from share value maximizing behavior. Since this discount comes completely out of the pockets of management when an initial offering of shares is made, management will have an incentive to include terms in the articles providing cost-effective constraints on its ability to deviate. See Jensen \& Meckling, Theory of the Firm: Managerial Behavior, Agency Costs and Ownership Structure, 3 J. FIN. EcoN. 305, 31219 (1976). This incentive is weaker for subsequent offerings since all the gains from the deviations go to management while the costs of the discount are shared with existing public shareholders. 
cial decisions, articles provisions involve restraints on management that have uncertain effects on share value. Thus the himitations of the market model evidenced by the Weiss and White findings raise questions as to whether the market actually takes note of such provisions and, if it does, whether it accurately reflects their implications. It is true that unlike the seven decisions, information concerning articles provisions is firm-specific, and this fact, if taken alone, increases the probabihity that it would be noticed by the market. This is counterbalanced by the fact that firmspecific information is of much less absolute miportance. In addition, such information is harder to obtain and more difficult to summarize than are the results of judicial decisions. ${ }^{64}$

The Weiss and White results also raise questions concerning the contractual theorists' basis for arguing that state corporate laws constrain managennent sufficiently without supplemental federal regulation. This is a concern because management effectively controls in which state a firm incorporates. If it is not forced to pay a sufficient price as a consequence of the resulting reduction in firm value, it would choose the state that would allow it the inost freedom to deviate from behavior that maximizes share value. This concern is the basis of Williain Cary's fear of a "race to the bottom" led by Delaware: State legislatures and judges will pander to the desires of management and compete to be the state that offers the least constraints in order to maximize franchise fee receipts. ${ }^{65}$ Contractual theorists maintain that this concern is not real. Because share prices, in their view, will accurately reflect the effect of the state of incorporation on share value, inanagers will be forced to pay a substantial price if they incorporate in a state that allows them to deviate from maximizing behavior. Instead, in order to attract top dollar for their shares, managers will incorporate in the states most favorable to shareholders and states will then compete in a "race to the top" to offer such laws. ${ }^{66}$

The Weiss and White results suggest that market prices may not play this role. If the explanation of their results is that the market either did not notice or did not accurately evaluate the changes in Delaware's judicial policy, the market may well also fail to account for differences

64. Questions remain even if the market accurately reflects the effects of the seven decisions and thus would also be expected to accurately reflect effects of the provisions of the articles of incorporation. The preceding discussion shows how difficult it is, even using the best statistical methods, to discern such market evaluations. One can fairly ask how likely it is that corporate managers will be aware that the market will react to their choice of articles terms or be able to predict the direction of that reaction.

65. See Cary, Federalism and Corporate Law: Reflections Upon Delaware, 83 YALE L.J. 663 (1974).

66. See, e.g., Winter, State Law, Shareholder Protection, and the Theory of the Corporation, 6 J. LEGAL STUD. 251, 289-92 (1977). 
among states in their corporate laws. ${ }^{67} \mathrm{~A}$ judicial decision, after all, is simply one component of the whole corporate law of a state and each decision affects all firms incorporated under that law. ${ }^{68}$ Even if this explanation of their results is incorrect, the Weiss and White results are damaging to the contractual theorists' empirical case against Cary's race to the bottom hypothesis. That case is based on the findings of Dodd and Leftwich that there is no statistically significant price reaction to reincorporation in Delaware. ${ }^{69}$ Weiss and White's failure to find statistically significant reactions to cases articulating major changes in Delaware law suggests that Dodd and Leftwich placed too high a burden of proof on Cary. Even if the market accurately evaluates the effects of Delaware reincorporations and these effects are negative in an anount that is economically important in aggregate, reincorporations may not be accompanied by statistically significant price changes.

Finally, Weiss and White's findings arguably undermine contractual theorists' approach to hostile takeovers because that approach is also premised on the accuracy of market prices. Questions arise in two areas: (1) What rules are appropriate to govern target managers' defense tactics? and, (2) What level of corporate law constraints on management is appropriate given the ability of a hostile takeover threat to align the interests of management with those of shareholders? With respect to the first concern, target managers typically claim that tender offer defenses are consistent with their fiduciary duties on the grounds that the offer price, although greater than market price before the bid, is less than share value. ${ }^{70}$ Contractualists, such as Easterbrook and Fischel, disagree

67. Weiss and White note this implication of the explanation of their results offered here, but the significance of their observation is diminished by the adoption of their explanation of the results. Weiss \& White, supra note 1 , at 587-90. They suggest that their explanation also creates difficulties for the contractual theorists' view of the "race to the bottom": "If investors do not find judicially wrought changes in corporate law to be significant, we believe it is unlikely that investors consider differences between different states' corporate laws to be significant." Id. at 602 . This critique is not very compelling because investors could well view the courts of two states as each, despite shifts in articulated rules, behaving consistently over time but differently from each other. For example, one might be consistently "promanagement" and the other consistently "proshareholder."

68. There are, of course, relevant differences between an analysis of the impact of a single judicial opinion on the value of the shares of a state's firms and an analysis of the impact of the state's whole corporation law. On the one hand, the latter analysis is far more complicated, thus reducing the effectiveness of the mechanisms that allow accurate market evaluations of some events. See supra text accompanying notes 20-49. On the other hand, as snggested above, each state may develop a general track record by consistently restraining management to one degree or another. This would make a comparison between the corporate laws of two states easier than a comparison between the law of one state before and after the announcement of a new judicial opinion. See supra note 67. Also the difference between the states is likely to be larger than the impact of a single decision, thereby making analysis more worthwhile. These two factors increase the chance that the mechanisms that allow some accurate market evaluations would work effectively here.

69. See Dodd \& Leftwich, The Market for Corporate Charters: "Unhealthy Competition" versus Federal Regulation, 53 J. Bus. 259, 277 (1980).

70. See Lipton, Takeover Bids in the Target's Boardroom, 35 Bus. LAwYER 101 (1979). 
because they assume that the market price before the hostile bid accurately reflects the value of the firm under the incumbent inanageinent. Therefore, they argue, target managers should be forbidden to defend against a tender offer $\mathrm{m}$ any way. ${ }^{71}$

The White and Weiss results raise questions as to how accurately share prices reflect the share value of target firms. Although the information required to evaluate the effects of seven Delaware decisions has more in common with the information required to evaluate the effects of the provisions of corporate articles and state corporation laws than with the information required to evaluate a firm's inanageinent and overall worth, all this information can be characterized as "soft." Thus, if facially "major" judicial decisions do in fact signal some change in judicial pohicy, the failure of market studies to reveal this may indicate more general market inefficiency with respect to soft information. This possibility weakens the contractual theorists' argument against tender offer defenses because, just as target inanagers contend, share values might soinetimes exceed tender offer prices.

With regard to the second question raised by the Weiss and White results regarding hostile takeovers, contractualists argue that legal restraints on management are largely unnecessary because the threat of hostile takeovers serves to align the interests of management and shareholders. Manageinent failure to maximize share value will cause share price to drop and precipitate a hostile tender offer; this is so because potential acquirors, knowing that the firm can be run more profitably, will regard the lower price as a bargain. The doubts raised here concerning the accuracy of the market price of the shares of a potential target firm weakens this argument because they inply that the takeover threat may not aligu the interests of managers and shareholders as effectively as the contractualists clain. If share price is too high, an unrestrained inanagement is given an additional ineasure of protection when it pursues its own interests rather than shareholder interests. If share price is too low, managers may lose control of firms to less efficient tender offerors and the level of activity in the takeover market will give outside observers an exaggerated impression of the threat to inefficient managers. Accordingly, the necessity of legal restraints on management may be greater than contractuahists suggest.

\section{CONCLUSION}

Weiss and White's explanation of their results have two important aspects in common with the contractual approach they purport to criticize. First, both are part of a "scientific" tradition in legal scholarship.

71. See Easterbrook \& Fischel, supra note 23, at 1174-82. 
Each seeks to describe the process that produces judicial decisions rather than the decisions themselves. Weiss and White emphasize the "music" that courts play rather than the "words" courts write as they "fine tune" corporate law to strike "an appropriate balance" between management and shareholders. ${ }^{72}$ Similarly, contractual theorists argue there is a "race to the top" in state corporate lawmaking. Second, in developing their models of process, both rely on market prices as accurate measures of the effects of legal decisions on share value.

Much can be learned about the legal process from market studies. Weiss and White's results almost certainly show that there is sufficient continuity im corporate law decisionmaking that the seven decisions do not represent dramatic changes in the legal environment in which management operates. ${ }^{73}$ The contractual theorist's "race to the top" at least shows that there exist forces, whatever their strength, working against those that create a "race to the bottom."

This emphasis on process, however, should not subsume the whole scholarly enterprise. The limitations of the market model make mcomplete the models of process utilized by Weiss and White and by the contractualists and call for studies of the legal process using a variety of social science techmiques. ${ }^{74}$ Equally important, scholars of the law should provide a normative critique of the products of judicial decisionmaking and that critique should go beyond saying that decisions are good or bad, simply because they were produced by a process with given characteristics. ${ }^{75}$ In particular, if a doctrinal principle articulated in a major decision has at least some value for predicting future judicial behavior, legal scholars should look at its social effects under the assumption that it will be applied in future cases. ${ }^{76}$ Moreover, studies of these

72. Weiss \& White, supra note 1 , at 597,598 .

73. The larger the actual effect of a decision on share value, the less likely it is that the effect will go undetected despite the flaws of the market model discussed here.

74. See, e.g., Romano, Law as a Product: Some Pieces of the Incorporation Puzzle, 1 J.L. EcoN. \& ORg. 225 (1985); Romano, The Political Economy of Takeover Statutes, 73 VA. L. REV. 111 (1987).

75. Thus, the utility of federal minimum standards of corporate law must be judged with reference to the actual decisions produced by state judiciaries, and not by the mere identification of forces that might generate a "race to the top." Similarly, the policy implications of the rules articulated in the seven decisions studied should be examined and not simply viewed as aspects of a process that uses flexible and fluid principles "to maintain an appropriate balance between the interests of shareholders and of managers." Weiss \& White, supra note 1, at 595.

76. When a legal scholar engages in such a substantive critique of judicial policy, he is likely to speak, as Weiss and White accuse the contractual theorists of speaking, of doctrinal statements in individual cases as if they state broad rules to be consistently applied in future cases. Id. at 594 . Speaking in this fashion does not necessarily reflect a naive view of the judicial process. Like the use of partial equilibrium analysis in economics, it is helpful, when a scholar explores the appropriateness of a given principle that is one among several used by courts to resolve a certain kind of issue, to examine the principle's implications as if it were the only principle used. 
effects should utilize the full range of available economic and other social science theories and empirical techniques, not the market model alone.

Weiss and White do not say that legal scholars should not critique the doctrinal statements of major decisions, but their explanation of their results certainly makes such scholarship sound unimportant. ${ }^{77}$ In fact, such scholarship is very important. As we have seen, it is likely that such doctrinal statements do have at least some predictive value. Furthermore, the Weiss and White model fails to recognize that judicial decisionmaking is a dynamic process in which such critiques serve as feedback. These critiques are influential because they clarify the policy choices available to judges and reshape the climate of authority in which judges must operate to reaffirm their legitimacy.

Thus, the debate among legal scholars as to the effects of important corporate decisions should not be foreclosed by Weiss and White's study. Use of the market inodel to measure the effects of events on share value and the contractual approach share some basic underlying assumptions about market pricing and the ease of detecting market reactions. The preceding interpretation of the Weiss and White results raises serious questions about those assuinptions. The ultimate lesson from this examination is that the market model and the contractual approach, while useful tools, are not substitutes for the full range of tools of inodern legal analysis.

77. Id. at 605 . 